\title{
Influence of Weather Factors on the Incidence of Major Pests and its Predators of Cotton
}

\author{
Yogesh D. Charjan and Nikita V. Patil* \\ Department of Agronomy, Dr. P.D.K.V, Akola, Dist- Akola, Maharashtra, India \\ *Corresponding author
}

\section{A B S T R A C T}

Field experiments was conducted during kharif season 2014-2015 to study the influence of meteorological factors on the incidence of major pests of cotton. Incidence of aphids was initiated in $32^{\text {nd }}$ MW (35.0/ leaf) and aphid population was lowest in $42^{\text {nd }}$ and $43^{\text {rd }} \mathrm{MW}$ (0.2/ leaf). It has attained its initial peak during $32^{\text {nd }} \mathrm{MW}$ (35.0/ leaf) which was favored by min. temp. of $31.99^{\circ} \mathrm{C}$ and max. temp. of $33.59^{\circ} \mathrm{C}$ with morning $95.86 \%$ and evening $78.86 \%$ humidity along with 10.0 $\mathrm{mm}$ rainfall. Incidence of leaf hoppers was initiated in $34^{\text {th }} \mathrm{Mw}(0.2 /$ leaf $)$ and thereafter continued

\section{Ke y w o r d s}

Cotton, weather parameters, pest, predators

\section{Article Info}

Accepted:

12 February 2020

Available Online:

10 March 2020 up to $42^{\text {nd }} \mathrm{mw}$ with disappearance in $43^{\text {rd }}$ and $44^{\text {th }} \mathrm{MW}$. It reached its peak during $36^{\text {th }} \mathrm{MW}$ (0.9/ leaf) which was favored by min. temp. of $31.87^{\circ} \mathrm{C}$ and max. temp. of $33.27^{\circ} \mathrm{C}$ with morning $96.71 \%$ and evening $87.43 \%$ humidity along with $60.60 \mathrm{~mm}$ rainfall. Incidence of thrips was initiated in $33^{\text {rd }} \mathrm{mw}$ (0.2/leaf). It was at its peak during $36^{\text {th }} \mathrm{MW}(0.6 /$ leaf $)$ which was favored by min. temp. of $31.87^{\circ} \mathrm{C}$ and max. temp. of $33.27{ }^{\circ} \mathrm{C}$ with morning $96.71 \%$ and evening $87.43 \%$ humidity along with 60.60 $\mathrm{mm}$ rainfall. Incidence of whitefly was first observed in $32^{\text {nd }} \mathrm{MW}$ (5.8/ leaf). It was at its peak during $32^{\text {nd }} \mathrm{MW}$ (5.8 Nymph/leaf ). The meteorological parameters were in range of min. temp. of $31.99{ }^{\circ} \mathrm{C}$ and max. temp. of $33.59{ }^{\circ} \mathrm{C}$ with morning $95.86 \%$ and evening $78.86 \%$ humidity along with $10.0 \mathrm{~mm}$ rainfall during $32^{\text {nd }} \mathrm{MW}$. Incidence of mite and mealy bug was not observed on cotton during the growing season. Predator activity was observed throughout the season form $32^{\text {nd }}$ MW to $48^{\text {th }}$ MW. Population of lady bird beetle was at its peak during $33^{\text {rd }} \mathrm{MW}$ (5.5/ plant) with meteorological parameters in the range of min. temp. of $31.90{ }^{\circ} \mathrm{C}$ and max. temp. of $34.16^{\circ} \mathrm{C}$ with morning $93.71 \%$ and evening $68.57 \%$ humidity along with $2.2 \mathrm{~mm}$ rainfall. Chrysopa population was not observed on cotton during the growing season. Population of spider was at its peak during $36^{\text {th }} \mathrm{MW}$ (0.4/Plant) during which meteorological parameters in the range of min. temp. $31.87^{\circ} \mathrm{C}$ and max. temp. of $33.27^{\circ} \mathrm{C}$ with morning $96.71 \%$ and evening $87.43 \%$ humidity along with 60.60 $\mathrm{mm}$ rainfall. Boll worm and red cotton bug damage was not observed on cotton during the growing season.

\section{Introduction}

The King of fibre Cotton (Gossypium hirsutum L.), is popularly known as White gold, an important cash crop in India. Among the various causes of low productivity of cotton in India, the insect pest is one of the major causes. In India, 200 species of insect pests have been reported to attack the cotton crop right from germination till the final harvesting of the crop.

The pests have the potential to reduce yield by 20 to 80 per cent. Few of them are considered as key pests causing huge damage to cotton crop all over the country. The major 
pests attacking on cotton are aphid, jassid, thrips, whitefly, mealybug, mite, red cotton bug and bollworm complex. The population of spider feeding on insect pests of cotton was observed throughout the growth period of the crop, being maximum in the month of July. Chrysopa was observed from second fortnight of June to harvesting of the crop being maximum in November.

The incidence of coccinellids was recorded from the middle of August to middle of September and remained till harvesting of the crop being maximum in the first fortnight of November. A positive significant effect of maximum and minimum temperature on spider and negative significant effect on population of chrysoperla and coccinellids was recorded. Evening RH exerted positive significant effect on spider and negative significant effect on coccinellids. (Dhaka and Bhanwarlal, 2007). To achieve the satisfactory suppression of these destructive insects pests, manipulating the sowing time, testing and evaluation of newer insecticides knowledge of seasonal incidence helps in planning need based application of insecticides.

\section{Materials and Methods}

Cotton variety AKA-8 was raised at $60 \mathrm{x}$ $15 \mathrm{~cm}$ geometry during third week of July 2014 in plot size of $10 \mathrm{~m} \times 10 \mathrm{~m}$ providing all agronomic practices at Agricultural Research Sub-Centre, Achalpur, Dr.Panjabrao Deshmukh Krishi Vidyapeeth, Akola. Weekly observation was recorded on 10 randomly selected plants. Aphids, leaf hoppers, thrips, whitefly and mite population count was recorded on top, middle and bottom canopy of each plant. Dropping shoots/ drying top shoots due to top shoot borer were also recorded on 10 randomly selected plants. Average number of aphids, leaf hoppers, thrips, whitefly, \& mite were calculated per leaf per plant. Percent infestation of plants due to top shoot damaged by spotted bollworm.

Total No. of green fruiting bodies (square, buds, flowers, and green bolls.) and those infested by bollworms, (spotted, American, pink) were recorded at weekly interval and workout the percentage infestation of bollworm (Spotted, American \& Pink bollworm). Mealy bug population count was also recorded on $5 \mathrm{~cm}$ tender twigs of cotton on 10 randomly selected plants and average out observation on $5 \mathrm{~cm}$ twig per plant. The data recorded on weekly incidence of major pest is presented in table No.1

\section{Results and Discussion}

Incidence of aphids was initiated in $32^{\text {nd }} \mathrm{MW}$ (35.0/ leaf) and aphid population was decrease and increased with subsequent MW up to $48^{\text {th }} \mathrm{MW}$ and was lowest in $42^{\text {nd }}$ and $43^{\text {rd }} \mathrm{MW}$ (0.2/ leaf). However it was observed throughout growing season up to $48^{\text {th }} \mathrm{MW}$. It has attained its initial peak during $32^{\text {nd }} \mathrm{MW}$ (35.0/ leaf) which was favored by min. temp. of $31.99{ }^{\circ} \mathrm{C}$ and max. temp. of $33.59{ }^{\circ} \mathrm{C}$ with morning $95.86 \%$ and evening $78.86 \%$ humidity along with $10.0 \mathrm{~mm}$ rainfall and $33^{\text {rd }}$ MW (8.4/ leaf) which was favored by min. temp. of $31.90{ }^{\circ} \mathrm{C}$ and max. temp. of $34.16{ }^{\circ} \mathrm{C}$ with morning $93.71 \%$ and evening $68.57 \%$ humidity along with $2.20 \mathrm{~mm}$ rainfall. Incidence of leaf hoppers was initiated in $34^{\text {th }} \mathrm{Mw}(0.2 /$ leaf $)$ and thereafter continued up to $42^{\text {nd }} \mathrm{mw}$ with disappearance in $43^{\text {rd }}$ and $44^{\text {th }}$ MW. Leaf hoppers population was reappearing in $45^{\text {th }} \mathrm{MW}$ and slowly increased and decrease with continued up to $48^{\text {th }}$ MW. It reached its peak during $36^{\text {th }} \mathrm{MW}$ (0.9/ leaf)which was favored by min. temp. of $31.87^{\circ} \mathrm{C}$ and max. temp. of $33.27^{\circ} \mathrm{C}$ with morning $96.71 \%$ and evening $87.43 \%$ humidity along with $60.60 \mathrm{~mm}$ rainfall, finding in lined with Kadam et al., 2015. 
Table.1 Incidence of major pest of cotton and their bioagents with meteorolgical parameters during 2014-15

\begin{tabular}{|c|c|c|c|c|c|c|c|c|c|c|c|c|c|c|c|c|}
\hline \multirow{2}{*}{$\begin{array}{l}\text { Sr. } \\
\text { No. }\end{array}$} & \multirow[t]{2}{*}{ MW } & \multirow{2}{*}{$\begin{array}{c}\text { Date of } \\
\text { Observation }\end{array}$} & \multicolumn{5}{|c|}{ Av. No. Sucking pest / leaves / pl } & \multirow{2}{*}{$\begin{array}{c}\text { M.B. } \\
\text { per } \\
5 \mathrm{~cm} \\
\text { twig/pl }\end{array}$} & \multicolumn{3}{|c|}{ Av. No. of Bioagent / pl. } & \multicolumn{5}{|c|}{ Weather Parameters } \\
\hline & & & A & LH & $\mathbf{T}$ & WF & $\mathbf{M}$ & & LBB & Ch & SPI & $\begin{array}{l}\text { Min. } \\
\text { Temp }\end{array}$ & $\begin{array}{c}\text { Max } \\
\text { Temp }\end{array}$ & $\begin{array}{c}\text { Hum } \\
(\mathrm{M})\end{array}$ & $\operatorname{Hum}(\mathbf{E})$ & $\begin{array}{c}\text { RF } \\
(\mathbf{m m})\end{array}$ \\
\hline 1 & 29 & - & - & - & - & - & - & - & - & - & - & 32.53 & 34.11 & 87.29 & 73.57 & 8.20 \\
\hline 2 & 30 & - & - & - & - & - & - & - & - & - & - & 31.97 & 33.09 & 95.71 & 85.29 & 107.80 \\
\hline 3 & 31 & - & - & - & - & - & - & - & - & - & - & 31.27 & 32.17 & 99.14 & 92.86 & 262.40 \\
\hline 4 & 32 & 11.08 .14 & 35.0 & - & - & 5.8 & - & - & 0.6 & - & - & 31.99 & 33.59 & 95.86 & 78.86 & 10.00 \\
\hline 5 & 33 & 18.08 .14 & 8.4 & - & 0.2 & 1.8 & - & - & 5.5 & - & - & 31.90 & 34.16 & 93.71 & 68.57 & 2.20 \\
\hline 6 & 34 & 25.08 .14 & 1.8 & 0.2 & 0.3 & 1.9 & - & - & 1.3 & - & - & 32.27 & 34.07 & 86.00 & 69.57 & 0.20 \\
\hline 7 & 35 & 01.09 .14 & 1.3 & 0.4 & 0.4 & 2.1 & - & - & 1.7 & - & - & 32.20 & 33.46 & 95.57 & 80.86 & 27.00 \\
\hline 8 & 36 & 08.09 .14 & 2.2 & 0.9 & 0.6 & 0.9 & - & - & 1.4 & - & 0.4 & 31.87 & 33.27 & 96.71 & 87.43 & 60.60 \\
\hline 9 & 37 & 15.09 .14 & 3.3 & 0.9 & 0.5 & 2.4 & - & - & 1.1 & - & 0.2 & 31.67 & 32.57 & 97.57 & 92.14 & 125.20 \\
\hline 10 & 38 & 22.09 .14 & 2.2 & 0.8 & 0.5 & 2.7 & - & - & 1.2 & - & - & 31.79 & 33.59 & 96.14 & 79.14 & 0.00 \\
\hline 11 & 39 & 29.09 .14 & 0.7 & 0.4 & 0.3 & 2.1 & - & - & 0.6 & - & 0.2 & 32.41 & 34.69 & 86.00 & 67.57 & 0.00 \\
\hline 12 & 40 & 06.10 .14 & 0.5 & 0.3 & 0.4 & 2.6 & - & - & 0.2 & - & 0.3 & 31.79 & 35.09 & 91.14 & 54.14 & 0.00 \\
\hline 13 & 41 & 13.10 .14 & 0.7 & 0.3 & 0.3 & 3.1 & - & - & 0.2 & - & 0.1 & 31.83 & 35.10 & 89.71 & 52.43 & 12.00 \\
\hline 14 & 42 & 20.10 .14 & 0.2 & 0.3 & - & 1.8 & - & - & - & - & - & 31.64 & 34.60 & 90.86 & 55.71 & 4.20 \\
\hline 15 & 43 & 27.10 .14 & 0.2 & - & - & 2.5 & - & - & - & - & - & 31.51 & 34.43 & 92.14 & 58.86 & 0.00 \\
\hline 16 & 44 & 03.11 .14 & 0.3 & - & - & 3.1 & - & - & 0.1 & - & 0.1 & 30.33 & 33.53 & 87.29 & 54.43 & 0.00 \\
\hline 17 & 45 & 10.11 .14 & 0.4 & 0.2 & - & 3.5 & - & - & 0.2 & - & 0.3 & 30.09 & 34.59 & 83.29 & 40.57 & 0.00 \\
\hline 18 & 46 & 17.11 .14 & 0.5 & 0.3 & - & 3.6 & - & - & 0.3 & - & 0.3 & 30.26 & 34.43 & 77.14 & 40.71 & 0.00 \\
\hline 19 & 47 & 24.11 .14 & 0.4 & 0.2 & - & 3.1 & - & - & 0.3 & - & 0.2 & 30.96 & 33.67 & 92.43 & 60.57 & 18.00 \\
\hline 20 & 48 & 01.12 .14 & 0.3 & 0.1 & - & 2.6 & - & - & 0.3 & - & 0.2 & 29.10 & 33.81 & 80.00 & 37.57 & 0.00 \\
\hline 21 & 49 & - & - & - & - & - & - & - & - & - & - & 28.91 & 33.94 & 84.14 & 37.71 & 0.00 \\
\hline 22 & 50 & - & - & - & - & - & - & - & - & - & - & 28.36 & 33.64 & 79.86 & 30.86 & 0.00 \\
\hline
\end{tabular}


Incidence of thrips was initiated in $33^{\text {rd }} \mathrm{mw}$ (0.2/leaf) and continued up to $41^{\text {st }} \mathrm{MW}$. It was at its peak during $36^{\text {th }} \mathrm{MW}$ (0.6/leaf) which was favored by min. temp. of $31.87^{\circ} \mathrm{C}$ and max. temp. of $33.27{ }^{\circ} \mathrm{C}$ with morning $96.71 \%$ and evening $87.43 \%$ humidity along with $60.60 \mathrm{~mm}$ rainfall followed by in $37^{\text {th }} \mathrm{MW}$ (0.5/leaf) which was favored by min. temp. of $31.67{ }^{\circ} \mathrm{C}$ and max. temp. of $32.57^{\circ} \mathrm{C}$ with morning $97.57 \%$ and evening $92.14 \%$ humidity along with $125.20 \mathrm{~mm}$ rainfall.

Thrips population recorded positive significant correlation with respect to minimum temperature, morning and evening humidity on cotton crop. Incidence of whitefly was first observed in $32^{\text {nd }}$ MW (5.8/ leaf) and continued slowly increase and decrease steadily up to $48^{\text {th }} \mathrm{mw}$. It was at its peak during $32^{\text {nd }}$ MW (5.8 Nymph/leaf). Similar finding for sucking pest reported by Harde et al., 2018.

The meteorological parameters were in range of min. temp. of $31.99{ }^{\circ} \mathrm{C}$ and max. temp. of $33.59{ }^{\circ} \mathrm{C}$ with morning $95.86 \%$ and evening $78.86 \%$ humidity along with $10.0 \mathrm{~mm}$ rainfall during $32^{\text {nd }} \mathrm{MW}$. followed by in $46^{\text {th }}$ MW (3.6/leaf) which was favored by min. temp. of $30.26{ }^{\circ} \mathrm{C}$ and max. temp. of $34.43{ }^{\circ} \mathrm{C}$ with morning $77.14 \%$ and evening $40.71 \%$ humidity along with no rainfall. Incidence of mite and mealy bug was not observed on cotton during the growing season.Boll worm damage was not observed on cotton during the growing season. Red cotton bug damage was not observed on cotton during the growing season.

Predator activity was observed throughout the season form $32^{\text {nd }} \mathrm{MW}$ to $48^{\text {th }} \mathrm{MW}$ with disappearance in $42^{\text {nd }}$ and $43^{\text {rd }} \mathrm{MW}$. Low population of lady bird beetle (0.1 to 5.5/ Plant) was recorded. It was at its peak during $33^{\text {rd }}$ MW (5.5/ plant) with meteorological parameters in the range of min. temp. of 31.90
${ }^{\circ} \mathrm{C}$ and max. temp. of $34.16{ }^{\circ} \mathrm{C}$ with morning $93.71 \%$ and evening $68.57 \%$ humidity along with $2.2 \mathrm{~mm}$ rainfall. Followed by $35^{\text {th }} \mathrm{MW}$ (1.7/ plant) with meteorological parameters in the range of min. temp. of $32.20^{\circ} \mathrm{C}$ and max. temp. of $33.46{ }^{\circ} \mathrm{C}$ with morning $95.57 \%$ and evening $80.86 \%$ humidity along with 27.0 $\mathrm{mm}$ rainfall. Chrysopa population was not observed on cotton during the growing season. Population of spider was initiated in $36^{\text {th }}$ MW (0.4/Plant) and continued up to $48^{\text {th }}$ MW with disappearance in $38^{\text {th }}, 42^{\text {nd }}$ and $43^{\text {rd }}$ MW. It was at its peak during $36^{\text {th }}$ MW (0.4/Plant) during which meteorological parameters in the range of min. temp. $31.87^{\circ} \mathrm{C}$ and max. temp. of $33.27^{\circ} \mathrm{C}$ with morning $96.71 \%$ and evening $87.43 \%$ humidity along with $60.60 \mathrm{~mm}$ rainfall. Similar finding reported by Chauhan et al., 2017.

\section{References}

D.B. Kadam, D.R. Kadam and Umate, S.M. 2015. Effects of weather parameters on incidence sucking pests on Bt cotton. International Journal of Plant Protection Volume 8(1), 211-213.

Harde S. N, Mitkari A. G, Sonune S. V and Shinde L. V 2018. Seasonal Incidence of Major Sucking Insect Pest in Bt Cotton and Its Correlation with Weather Factors in Jalna District (MS), India. International Journal of Agriculture \& Environmental Science5(6), 59-65.

R.P. Chauhan, M.V. Vekaria, H.K. Chaudhary andChaudhary, N.J 2017.Seasonal incidence of sucking pests and their natural enemies in $\mathrm{Bt}$ cotton. Journal of Entomology and Zoology Studies 2017; 5(5): 1274-1282.

S.R. Dhaka and BhanwarLal P. 2007.Seasonal Incidence of natural enemies of key insect pests of cotton and their relationship with weather parameters.Journal of Plant Protection Research. 47(4), 417-423. 


\section{How to cite this article:}

Yogesh D. Charjan and Nikita V. Patil. 2020. Influence of Weather Factors on the Incidence of Major Pests and its Predators of Cotton. Int.J.Curr.Microbiol.App.Sci. 9(03): 1778-1782.

doi: https://doi.org/10.20546/ijcmas.2020.903.206 